\title{
The Eye/I of the Other: Self and Audience in Wordsworth's Lyrical Ballads
}

W ritten at about the same time as the conversation poems and even incorporating two of them, the Lyrical Ballads initially seem an expansion of the former to include people from all walks of rural life in a community of sympathetic conversants. Wordsworth's project can be paralleled with that of Dilthey, who begins with a sense of hermeneutic difference but who concludes that a common substratum of human nature allows us to understand the other by translating what is external to us out of our "own sense of life." Many of the poems represent people who differ in terms of age, class, or occupation talking to each other. The preface in effect announces a hermeneutic program: in turning to a popular form purged of poetic diction, it seeks to bind such people together by creating a common language based on the "elementary feelings" that we share ( $L B$, p. 245). In other words, it enlists poetics in the service of hermeneutics by arguing that poetry can facilitate understanding across social boundaries. More specifically, it expands hermeneutics in a social direction by making the sharing of feelings the foundation for the establishment of transcultural values. Not only does the preface develop traditional hermeneutics in an explicitly ideological direction; the poems themselves seem to work out, through such hermeneutic figures as 'tradition' and 'circulation,' the cultural mechanisms necessary to universalize that ideology.

Yet it is significant that for Wordsworth the hermeneutic project emerges at a linguistic site: that the ideal of complete understanding is linked to an awareness that language must be purged of its social markings for such hermeneutic transparency to occur. Coleridge was later to question whether Wordsworth had succeeded in this goal $(B L$, II,3o- 
31). But because of its heteroglossic inclusion of different voices, the Lyrical Ballads itself inscribes its project in a social text that causes us to reflect on romantic ideals of sympathy and community. The creation of a social hermeneutic thus becomes implicated in a social dialogic that makes us aware of how our languages diverge. ${ }^{1}$ This awareness develops logically from Wordsworth's stated interest in "the fluxes and refluxes and refluxes of the mind" ( $L B$, p. 247) and from a radicalization of the romantic concern with perception. Such a concern survives conservatively in later arrangements of the short poems according to faculties like imagination and affection and stages of life like youth and old age. The 1815 classification naturalizes perception by explaining it in terms of universal psychological categories. But instead of grouping poems of one type in a self-confirming series, the Lyrical Ballads juxtaposes different types of poems so as to sensitize us to the issue of sociolects, of how discourses are formed and cultural texts constructed. The collection thus becomes the scene of its own reading, eroding further the protective boundary between the conversational and the dialogical. Incorporating poems like "Tintern Abbey," it also situates them, so that conversation is no longer their operative mode but is itself a figure of understanding.

\section{The Ballad as Mirror-Stage}

The motives that precede and emerge from Wordsworth's experiments with the ballad compose something of a palimpsest. Because of its simplicity and its association with folk tradition, the ballad seems closer to the unadorned truth than more cultivated forms. Thus Wordsworth talks of using "the real language of men" and of choosing "Low and rustic life . . . because in that situation . . . our elementary feelings exist in a state of greater simplicity" $(L B$, pp. 241,245$)$. Written in a 'real' language that denies the represented status of the text, the ballad provides an anthropological authority for the truths it conveys by linking them with a return to origins: the nature that precedes culture, the feelings that precede literary expression, and the popular forms closest to beginnings. But against the truth claim made by the ballad we must also set its association with the topical. Lennard Davis reminds us that ballads and novels are linked with the new and with the transmission of

1This chapter owes a considerable, if unspecific, debt to Don Bialostosky's fine book Making Tales: The Poetics of Wordsworth's Narrative Experiments (Chicago: University of Chicago Press, 1984), which uses a Bakhtinian approach to the shorter poems. In general, the use I make of Bakhtin is more oriented to the social than Bialostosky's appropriation of him. 
'news,' and it is well known that the broadside ballad constituted an early form of journalism. ${ }^{2}$ Characteristic of such ballads is a concern with events that are not simply recent, but that potentially touch our own lives so that we are "both object and subject, both reader of events and participant in those events." This immediacy can be seen as part of the ballad's claim to authenticity, as Davis argues. But on the other hand the rapid dispersion of news gives it a certain ephemerality, for as Davis also argues, from the late seventeenth century onward it is print and not orality that is associated with legitimation. Broadside ballads, while printed, are printed in a loose-leaf form that is vestigially oral and thus makes their authority merely provisional. ${ }^{3}$ Upon issue, they enter the space of dissemination, an unprotected space very different from that of literary patronage, the conversational circle, or institutional reception into the archives of libraries. As important is the fact that ballads have no authors, an aspect of the genre that Wordsworth and Coleridge preserved in issuing the Lyrical Ballads anonymously. What stands behind the ballad is not an authorizing figure whose credentials we can trust, but 'tradition': something amorphous, indicating survival but not in any classical sense, because what is transmitted through the generations is partly hearsay, superstition, legend.

We can best describe the status of Lyrical Ballads by saying there are tensions embedded in the ballad genre that both invite and problematize the project of the collection. Whether the Lyrical Ballads introduced a new poetic form has been much debated. But what seems unique about them is their inclusion not only of traditional and broadside ballads, but also of personal lyrics like "Tintern Abbey" and the Lucy poems, which relate not to legend but to Wordsworth's own experience. These lyrics are quite distinct from the lyric 'songs' that coexist in collections of folk poetry with narrative ballads, ${ }^{4}$ since they are in no sense communal. They are often what Geoffrey Hartman calls 'credal lyrics' that enunciate the poet's values: his sense of a 'one life' that links man to nature, his respect for a common humanity, and his advocacy of a 'wise passiveness'

${ }^{2}$ Lennard Davis, Factual Fictions: The Origins of the English Novel (New York: Columbia University Press, 1983), p. 48. On the subject of the ballad as journalism see also Albert Friedman, The Ballad Revival: Studies in the Influence of Popular on Sophisticated Poetry (Chicago: University of Chicago Press, 1961), pp. 46-49; M. A. Shaaber, Some Forerunners of the Newspaper in England, 1476-1622 (Philadelphia: n.p., 1929), pp. 196-97.

${ }^{3}$ Davis, Factual Fictions, pp. 73, 139-45. Broadsides were of ten discarded af ter reading: see Leslie Shepard, The Broadside Ballad: A Study in Origins and Meaning (London: Herbert Jenkins, 1962), p. 23.

${ }^{4}$ On Joseph Ritson's distinction between 'song' and 'ballad' see S. B. Hustvedt, Ballad Criticism in Scandinavia and Great Britain during the Eighteenth Century (New York: American Scandinavian Foundation, 1916), p. 254. 
that achieves culturally unmediated contact with the forms of nature. ${ }^{5}$ They do not always project experiences of communion with a pantheistic nature. What they share is an insistence on private feeling as a value in itself. Deriving from the sentimental tradition as opposed to the documentary tradition of the novel as news, the credal poems center on personal moments, desocialized and arrested in a crystalline space as spots of time, registers of change that have been placed and tranquilized. Although this poetry of the sentiments is at its purest in the personal lyrics, the same voice is present in more dialogical poems like "The Old Cumberland Beggar" and "The Idiot Boy," trying to wrest a lyrical epiphany from situations that a novelist might have rendered very differently. The impulse behind the collection is thus the naturalizing of a poetics of subjectivity: a poetics that would otherwise seem a romantic imposition on a world already encroached upon by the new discourses later developed by thinkers like Marx. Ordinary experiences from the poet's life (a conversation with a landscape, the death of someone whose importance was felt only by him) are set beside experiences in the lives of other ordinary people. These personal myths, instead of being enshrined as Keats says "in some untrodden region of the mind," then pass into the realm of the collective and are "incorporated with the ... permanent forms of nature" and human nature ( $L B$, p. 245).

The desire underlying the Lyrical Ballads, then, is to legitimize the discourse of the feelings that Wordsworth was beginning to develop in working with "The Ruined Cottage," by associating it with the communal form of the ballad. The difficulties of such legitimation can be considered in terms of the related problems of place and audience. For the politics of reading implied in this desire is both more ambitious and more dangerous than the one contained in the conversation poems. The Lyrical Ballads includes a wide variety of modes from romance to irony. It aims at being a Gesammtkunstwerk, crossing historical and class boundaries rather than boundaries between the sister arts, so as to create a universal community constituted around respect for the feelings. This community joins the pantisocratic middle class of the conversation poems to a rural middle class of shepherds whose strong sense of place is occupational and pragmatic rather than literary, and it tries to absorb various displaced people like the female vagrant and the Cumberland beggar. We might thus describe the project behind Lyrical Ballads as 'localization.' In his local poems, whether they deal with numinous spots in nature or with people who are strongly a part of the region where

${ }^{5}$ Wordsworth's Poetry, $I_{787-1814}$, rev. ed. (New Haven, Conn.: Yale University Press, $1971)$, p. 157. 
they live, Wordsworth tries to 'place' his own discourse by creating a real world for it. Discussing the social phenomenology of art forms, Wilhelm Worringer associates abstraction with a sense of not being at home in the world and the realistic attention to detail with the opposite. ${ }^{6}$ But in Wordsworth's poetry from 1798 onward we have both styles of awareness: the prosaic attention to facts that Coleridge criticized in the Biographia, as well as a language of abstract pantheistic generalization asserted rather than grounded in the particulars of experience. Because the two coexist, Wordsworth's realism emerges as a form of desire. This displacement of realism is evident in his sense that he does not quite belong in the small rural community where most of the poems are set. For Wordsworth often represents himself as Coleridge describes him: namely, as a spectator $a b$ extra seeking instruction on local lore from the natives of the place. His dislocation is symptomatically related to a curious interest in displaced people quite unlike himself: in beggars, women, and old people, who are likewise on the margins of this tightly knit community. As displaced figures, the two are linked in the rhetorical economy of the collection: to find a place for one alien discourse is to legitimize the other. On the question of whether these people can find a home in Wordsworth's imaginary community depends the question of whether he must encounter the prospect in his mind as a human community or whether he must live it as uneasily displaced from its own center by the consciousness of what it excludes.

Related to the problem of place is that of reception. Wordsworth's use of the ballad genre is uneasily eclectic, drawing as he does on both traditional and broadside forms. In imitating eighteenth-century ballad collections that haphazardly combine the two forms, ${ }^{7}$ Wordsworth may not have been initially aware of the differences between the two types and may have been attracted by what seemed an ageless and classless form. Nevertheless, the two kinds of ballad are aimed at very different audiences, and in conflating them, he creates a palimpsest in which the genre's claim to classlessness overlaps with a sense of the audience as a site of social differences. The traditional oral ballad, though popular, is not addressed to any particular class, nor are its concerns social or political. It may well express archetypal experiences that can be translated into the high mimetic modes of the romantic and heroic ballad as well as into low mimetic narratives of the folk. Broadside ballads, however, were

${ }^{6}$ Abstraction and Empathy: A Contribution to the Psychology of Style, trans. Michael Bullock (Cleveland and New York: Meridian Books, 1967), pp. 4-25.

${ }^{7}$ On the differences between the traditional and broadside ballad see Friedman, The Ballad Revival, pp. 11-63. The marginalization of the broadside ballad is characteristic of theories that, like F. B. Gummere's theory of the ballad as expressive of a communal spirit, 'romanticize' the genre. 
a later form developed within a literary economy with greater class differentiations. They were sold to an audience that was not essentially a reading public, and in the course of the nineteenth century became more and more a lower-class genre. ${ }^{8}$ As precursors of the cheap paperback, their concerns were quite diverse. They dealt with news, with melodramatic stories that admittedly turned social history into potboiler, and on occasion they became purveyors of radical politics. ${ }^{9}$ Often the experiences they described were ones produced by the class system, not ones that transcended it. We have only to turn to other writers like Scott and Keats to recognize that Wordsworth was unusual in drawing more on the broadsides than on the traditional ballads, and that his interest in the genre is social, not antiquarian. Although it is unlikely that the actual readers of the Lyrical Ballads included beggars and vagrants, since the poems were not issued on broadsheets, what concerns us here is the implied audience of the collection as a reactive or dialogical constituent of individual texts. Wordsworth's collection uneasily inhabits a split between two audiences from which the credal voice is likely to encounter very different receptions. The presence of these two audiences accounts for a hermeneutic anxiety in the collection, evident in the fact that so many poems are concerned with someone's telling a story to someone else or trying to convince someone of another point of view.

The polygenous reception history of the ballad makes it a convenient paradigm for problems that are more generally present in firstgeneration romantic poetry. Most of these poets still sought patrons and to a limited degree had them. But as Wordsworth complains, they also had to support themselves through publication. ${ }^{10}$ A system involving circulation within an intimate circle thus coexists with one involving distribution to a much wider audience. That the values even of a middleclass audience may be different from those of the poet is evident from Peacock's not entirely ironic account in The Four Ages of Poetry of the outmoding of 'poetry.' Because of its heteroglossic genre, the Lyrical Ballads becomes the scene of a discovery profoundly at odds with the assumptions of romantic hermeneutics: that 'audience' is neither a stable nor a homogeneous category.

Our remarks so far suggest that the ballad functions as a psychic screen on which desires having to do with ideological authority and

${ }^{8}$ See S. B. Hustvedt, Ballad Books and Ballad Men (Cambridge, Mass.: Harvard University Press, 1930), pp. 197-98; J. S. Bratton, The Victorian Popular Ballad (Totowa, N.J.: Rowman and Littlefield, 1975), p. 137.

${ }^{9}$ Shepard, The Broadside Ballad, p. 26; Bratton, The Victorian Popular Ballad, p. 137.

${ }^{10}$ See John E. Jordan, Why the Lyrical Ballads? The Background, Writing, and Character of Wordsworth's I798 Lyrical Ballads (Berkeley: University of California Press, 1976), pp. 2425 . 
hermeneutic community are projected and analyzed. The contrary pulls to which Wordsworth becomes subject in using the genre have to do with its complex archeology and long history. But in this respect it is simply one instance of the tendency of genres to become cultural palimpsests inhabited by the traces of more than one ideology. Perhaps the tendency of this genre to function as mirror and mirror-stage stems from the fact that the literary revival of the ballad coincides with its scholarly recovery. One example of the problems raised by scholarship is the debate over the popular minstrels whom Percy romanticized, and whom Ritson saw as little short of vagabonds. ${ }^{11}$ On their position hinged not only the authority of the minstrel ballads, but also the ideal of a feudal society with a literature that bridged the gap between popular and aristocratic forms of consciousness. To what extent was this idea of a multeity in unity, of a pluralist society that had classes but without class divisions, simply a romantic fiction? At the time Wordsworth was writing, the career of Thomas Chatterton, who not only passed off modern inventions as ancient discoveries but fabricated historical documents from the 'Rowley world' to buttress his case, ${ }^{12}$ must have cast further doubt on the anthropological and archeological legitimation of romantic norms. The editing of the ballads raised other problems, not clearly articulated till the mid-nineteenth century, but having to do with concepts fundamental to traditional hermeneutics like 'author' and 'origin.' For the ballad poses a challenge to the myth of the author as a locus for a fixed meaning, a myth that Wordsworth himself was to promulgate in his account of his early years as a prelude to his assumption of post-Miltonic authority. Ballads have no authors and do not exist in fixed versions. Although they may not be heuristic texts, they are instances of what H. R. Jauss calls a pre-autonomous literature that functions heuristically for us in allowing later readers to question a substantialist conception of literary works.

Research on the ballad participated in that larger movement that Lee Patterson describes in terms of "the analytic dissolutions of historicism," 13 a movement that reluctantly prefigures the theoretical dissolutions of deconstruction. Like the textual criticism of Beowulf, ballad criticism did not actually dispense with the idea of an original text until the mid-nineteenth century. In 1847 Svend Grundtvig, drawing on a principle urged twenty years earlier by the Scottish editor William Motherwell,

${ }^{11}$ Friedman, The Ballad Revival, pp. 215-19; Hustvedt, Ballad Criticism, p. 191.

${ }^{12}$ See Donald S. Taylor, Thomas Chatterton's Art: Experiments in Imagined History (Princeton, N.J.: Princeton University Press, 1978), pp. 44-78.

13"The Logic of Textual Criticism and the Way of Genius," in Jerome J. McGann, ed., Textual Criticism and Literary Interpretation (Chicago: University of Chicago Press, 1985), pp. $76-79$. 
published an edition containing multiple versions of ballads and assigning them equal authority. But Percy still believed in a stable, original text corrupted into a babel of versions by the errors of transmission. ${ }^{14} \mathrm{Nev}$ ertheless, ballad scholarship was entwined with the far more advanced line of Homeric scholarship that culminated in F. A. Wolf's Prolegomena ad Homerum. ${ }^{15}$ Wolf's careful research disintegrated the notion of the Homeric poems as created by a single intention and saw the extant texts as authorially composite writings made up of layers of altering, editing, and imperfectly disguised attempts at unification. Wolf's empirical findings were far more remarkable in their impact than the traditional hermeneutic that led him to short-circuit them through a stemmatic theory that posited a lost original. For those findings led to a certain desacralization of ancient texts, a fear that the recreation of the spirit behind them might not prevail against the analytic dissolutions set in motion by textual study.

How closely Wordsworth knew the new philology is not crucial. ${ }^{16}$ The point is that its problems are so deeply embedded in the ballad genre that they will emerge in any serious (as opposed to exotic) recreation of the form, whether academically through editing or fictionally through imitation. Wordsworth may have approached the ballad with a mystical concept of a folk authorship that was collective but unitary, open enough to provide a home for his own very different voice, yet sufficiently homogeneous not to relativize it in a collage of discourses. His assumptions about the ballad may have been those of F. B. Gummere, who later argues for a ballad tradition that is "Unwritten, just as ordinary experience is unwritten," and defines the ballad as "a narrative lyric handed down from generation to generation of a homogeneous and unlettered community". 17 What Wordsworth would have found, however, was a culture that was heterogeneous, a fabric of texts. The philological problems that arise as ballad scholarship becomes more sophisticated are homologous to hermeneutic problems that Wordsworth encounters as he reads the social text and his own position in it. To begin with, there is the marking of the text as text that occurs when a body of writings is submitted to scholarly scrutiny. Then there is the challenge to author(ity) that stems from the fact that ballads are relayed rather than originated. Percy's romanticized theory of the minstrel, so influential on

${ }^{14}$ Hustvedt, Ballad Criticism, pp. 3-7, 227.

${ }^{15}$ Friedman, The Ballad Revival, pp. 251-55, 172.

${ }^{16}$ There was presumably some awareness of the problems raised here among romantic writers. Thus Jerome McGann argues that Blake would have known the new developments in textual studies through the work of Alexander Geddes: "The Idea of an Indeterminate Text: Blake's Bible of Hell and Dr. Alexander Geddes," Studies in Romanticism 25 (1986): 303-24.

${ }^{17}$ F. B. Gummere, The Popular Ballad (1907; rpt. New York: Dover, 1959), p. 43. 
poets like Beattie, seeks to deflect that challenge by positing a minstrel who is spokesman for his culture. But Wordsworth's narrators do not afford us this panoptic gaze, being shepherds and sea-captains who do not understand the full import of what they are saying and whose stories are already within an interpretive chain. Finally, there is the problem that ballads exist only in versions. There are no original texts of the ballads, nor does tradition, as Gummere argues, function in place of the author by "effacing" variations and forcing the different versions into a historical consensus. ${ }^{18}$ Providing us only with versions of truth, Wordsworth's ballads force us to attend to the slight variations that mark the different ways stories are told in different sociolects.

The Hermeneutics of the Personal Voice: Inscription, Tradition, and Circulation

Wordsworth's project, as we have suggested, is the legitimation of a personal voice that believes in a community based on the feelings and that lyricizes narratives of loss and destitution so as to make them sublimatory preludes to vision. It seems appropriate to speak of 'voice' before we speak of 'form,' partly because this voice is an intention that cannot but be displaced in its articulation, and partly because it takes more than one form, and our understanding of it develops in the gap between these forms, and finally because in attempting to understand it as something that never successfully takes form, we recognize that it is never a unified voice. In giving voice to a romantic ideology, Wordsworth, like Coleridge, makes use of a positive hermeneutic, according it a social role as a way of binding people together and cleansing the doors of perception. But unlike Coleridge, he represents this voice and its strategies of legitimation as already under erasure. While the reflexive reading of the conversation poems is an aftereffect generated by their attempt to function hermeneutically rather than referentially, Wordsworth's choice of the collection rather than the autonomous lyric already situates his hermeneutic in the scene of its own reading. For the Lyrical Ballads initially impress us with their heterogeneity, and any attempt to unify them under the rubric of a 'project' is thus a psychological reading based on the articulation of this project in the preface or in other poems. That we must find it outside the poems themselves, that this project is in a sense our hermeneutic construction, makes these poems fundamentally different from Wordsworth's extended conversation poem The Prelude. For it marks his recognition that this project is supplementary, and that 
the subject who pursues it is not the transcendental subject (author or reader) of traditional hermeneutics, but is already within the social text that he tries to rewrite by inserting himself into it.

The personal voice and the positive (rather than dialectical) hermeneutic that it promotes are fundamentally conservative. David Sampson notes that Wordsworth's almost obsessive interest in the rural poor does not translate into a concern with the "social and political implications" of their situation." 19 More approvingly, Robert Langbaum argues that "Wordsworth alludes to social class only to show its unimportance for the kind of spirituality he is portraying." 20 The elision of the political takes the form of a reduction of narrative to lyric tableau that constructs the world in terms of feelings rather than events or situations. Thus a poem like "The Old Cumberland Beggar" focuses on the pleasure that individuals derive from acts of charity rather than on the economic conditions that lead to beggary. The emphasis on feeling perpetuates and is supported by a hermeneutics of sentimentalism. For the tradition of sentiment, as James Averill describes it, deemphasizes narrative to focus on response: on the telling of a sad story to a listener whose reactions draw the reader into the community of those who feel for others. ${ }^{21}$ Sentimentalism, stressing as it does what unites rather than what separates us, is linked to an elision of those differences that make a more dialectical hermeneutics part of a political project. But those differences are inscribed in the very genre Wordsworth chooses. As we consider his displacement of the conservative social hermeneutic he tries to legitimize, we shall focus on such things as the figures he uses to establish it, the audience as a dialogical constituent of the texts, and the forms assumed by the personal voice as displacements of the intentionality behind it.

The rural setting of Lyrical Ballads is an important figure in the representation of Wordsworth's responses as 'natural.' But other strategies are used in legitimizing the discourse of the feelings, among them what we shall call 'inscription,' 'tradition,' and 'circulation.' These hermeneutic figures are by no means unproblematic. The first of them, inscription, involves an anxious textualization of another metaphor of epistemic authority, incorporation. Wordsworth introduces this figure in the preface, when he speaks of feelings that are "incorporated with the . . permanent forms of nature" ( $L B$, p. 245). Often nature will give substance to a character's feelings by seeming to embody them in a specific place.

\footnotetext{
19"Wordsworth and the Poor: The Poetry of Survival," Studies in Romanticism 23 (1984): $5^{\mathrm{o} .}$

20"Wordsworth's Lyrical Characterisations," Studies in Romanticism 21 (1982): 320.

${ }^{21}$ Wordsworth and the Poetry of Human Suffering (Ithaca, N.Y.: Cornell University Press, $1980)$, p. 24 .
} 
In "The Brothers" she incorporates the boys' devotion to each other in the "brother fountains" and then incorporates the violent prematurity of James's death by destroying one of the fountains (ll. 139-46, $L B$ ). Behind incorporation is the powerful trope of the book of nature, which underwrites our moral construction of the world by creating a correspondence between words and things. The metaphor of inscription both continues and problematizes this figure by writing, not embodying, personal myth in the public domain. The clearest instances of inscription are the poems on the naming of places, but several other poems added in 1800 testify to what is almost an obsession with the mode. ${ }^{22}$ Moving beyond the occasional status of the mode in neoclassical poetry, Wordsworth's poems colonize an imaginative terrain so as to further the project of localization. For even though they are occasional, as the only poems in the collection that are accorded their own advertisement, the poems on the naming of places make the more ambitious claim of a literary cycle. Experiences from personal life are associated with specific places so as to render them permanent, part of a spatial rather than temporal order, while also recreating various un(re)marked spots through the mythmaking of the ordinary imagination: "By Persons resident in the country and attached to rural objects, many places will be found unnamed or of unknown names, where little Incidents will have occurred, or feelings been experienced. . . From a wish to give some sort of record to such Incidents or renew the gratification of such Feelings, Names have been given to Places by the Author and some of his Friends $(L B$, p. 217$)$.

What Wordsworth describes here as "naming" is linked in the note to the second poem with the greater antiquity of inscription, which literally writes such experience onto the rocks of Cumberland and Westmoreland. Yet naming is not inscription, and inscription itself is the textual imposition of meaning on the natural scene. As attempts to create a new fund of communal lore that will take its place among existing traditions, these poems have an anxiously recent quality. They transplant the circumscribed circle of the conversation poems into a community curiously void of local people, except for some mandatory "shepherds" (l. $42, L B)$ and a vicar who is allowed to speak thirteen words (ll. 23-24, $L B$ ). With the exception of a meeting with a leech-gatherer, the experiences inscribed do not transcend the realm of private allusion. The longest poem, "To Joanna," vaguely commemorates "affections old and true" (l. $81, L B)$. Abstract as they are, the poems do not accomplish their project

${ }^{22}$ I ref er to "Inscription for the Spot where the Hermitage stood on St. Herbert's Island, Derwent-Water," "Inscription for the House (an Outhouse) on the Island at Grasmere," "Lines Written with a Slate-Pencil upon a Stone, \&c.," "Lines Written on a Tablet, in a School," and "A Poet's Epitaph." 
of carving out a place for themselves in regional literature, but rather name, in a circular way, the inscriptive function itself. This is not to suggest that they are textually self-conscious poems, but rather that they explicitly mark for us a trope that functions less visibly in other poems, and thus lay the groundwork for the self-critical playing out of that trope that occurs in a more complex poem like "Lines Left Upon a Seat in a Yew Tree."

In this poem literal inscription is deliberately criticized so as to displace the inscriptive authority claimed by the text itself. The solitary who has trained the tree "to bend its arms in circling shade" (l. 11, $L B)$ has written into nature his own self-encircling withdrawal, "tracing here /An emblem of his own unfruitful life" (ll. 28-29, $L B$ ). Because he is now dead, a monumental writing closed to the complexities of life is tacitly associated with entombment. But Wordsworth's response to the solitary's inscription is equally closed in its moralizing complacency. As far as he is concerned, love of nature leads unproblematically to love of humanity, in ways that are merely asserted. The insecurity of Wordsworth's creed is evident in the fact that he addresses the poem as much to himself as to the traveler, dividing himself into instructor and pupil and speaking as resolved soul to another self that is still traveling. The speaker of the poem concedes the provisionality of his own response in merely pinning some lines to the seat rather than inscribing them, a gesture that is of paradigmatic significance for the status of Wordsworth's creed in the collection as a whole. These lines lack the epigrammatic closure of the traditional inscription and take form as a much longer text that exhibits the fluxes and refluxes of his mind and is thus subject to further reading. They also lack the impersonality of the inscription. Spoken in a distinctly personal voice, transcribed on paper rather than carved in rock, and left there for an unspecified 'Traveler' to read, they allow the reader to affirm, reject, or simply situate them.

If incorporation and inscription claim an identity between discourse and truth, tradition and circulation are figures of communication that create a transhistorical audience for this discourse. Tradition, so crucial to the ballad, facilitates the transmission of communal wisdom through the generations and thus the ratification of this wisdom by time. Among the traditional ballads are those that simply map a rhetorical space. "Ellen Irwin," for instance, is there to make the point that the regional tradition includes antique ballads as well as more recent ones like "Ruth" and thus to allude to the endurance of the past and present into the future. Tradition is subtly conservative, eliding the socioeconomic specificities of a poem like "Ruth" by suggesting that tragic love tales are archetypical. Its horizontal equivalent is circulation, the passing around rather than the handing down of shared insights. Jon Klancher has 
described the conservatizing role of reading in the economy of circulation, whether it occurs through readings and conversations in coffeehouses, or through periodicals and memberships in circulating libraries. The orderly circulation of material through such groups was meant to unite its members within "a knowable community of discourse." Drawing on Arthur Young's Travels in France written during the French Revolution, Klancher distinguishes between "circulation" as an activity designed to draw new groups into an existing consensus, and "dissemination," the propagandistic issuing of texts to anonymous readers at the other end of a polarized social spectrum without the safeguards of an intimacy between author and reader. ${ }^{23}$ "Tintern Abbey" like other conversation poems dramatizes the ideal of circulation, the transmission of insights within an intimate circle of friends. But Wordsworth himself uses the figure and expresses the hope that his poems might "circulate" among the people: a hope that is figured in his many representations of himself in dialogue with humble people. Circulated rather than disseminated, Wordsworth's texts claim to share their insights with others rather than to dispense their wisdom from a position of authority. They are passed around without the impersonality of dissemination and thereby hope to avoid dissemination in its more contemporary sense of a critically different appropriation by a reader who is not obliged by fictions of intimacy to accept the authority of the text.

Tradition and circulation are figures of transmission that assume that because of our common humanity, we can bridge the distances between people. Wordsworth speaks elsewhere of how a writer must create the taste by which he is to be enjoyed, ${ }^{24}$ and these figures are clearly part of his attempt in Lyrical Ballads to make his own audience. But as we have already suggested, Wordsworth's real and desired audiences were not identical, and the discrepancy is reactively felt as an uncertainty even as to his desired audience. Thus he sometimes indicates his desire for an audience wider than that of the conversational circle: "I have many a time wished that I had talents to produce songs, poems, and little histories, that might circulate among other good things in this way, supplanting partly the bad; flowers and useful herbs to take the place of weeds. Indeed some of the Poems which I have published were composed not without a hope that at some time or other they might answer this purpose." 25 But as the natural-cum-political word "(sup)plant" implies, the

${ }^{23}$ Jon Klancher, The Making of English Reading Audiences, I790-I 832 (Madison: University of Wisconsin Press, 1987), pp. 20, 28-35.

${ }^{24}$ Wordsworth, "Essay Supplementary to the Preface," in Paul M. Zall, ed., Literary Criticism of William Wordsworth (Lincoln: University of Nebraska Press, 1966), p. 182.

${ }^{25}$ Letter of 5 June 1808 in E. de Selincourt, ed., The Letters of William and Dorothy Wordsworth: The Middle Years, I806-1820, rev. Mary Moorman and A. G. Hill, 2 vols., 2nd ed. (Oxford: Clarendon, 1969-70), I, 248. 
legitimacy that a popular audience confers may involve an act of usurpation. However much Wordsworth hoped to have his poems circulate among the people, the fact is that they were initially printed as a volume and sold to an educated public. Thus one is never sure if the poems are aimed at the middle class or the people. If they are intended to challenge the discursive categories of an urban middle class, their new ways of shaping reality through language are representations constructed by a writer who is still part of the class from which he departs. If they are aimed at the people, we can question whether they did indeed meet their goal. Lyrical Ballads sold reasonably well, and some of its poems were reprinted in periodicals. ${ }^{26} \mathrm{~A}$ very few were reprinted on broadsheets, and because broadsheets were read aloud in pubs, it is possible that they reached a different class. But as H. D. Rawnsley reminds us, Wordsworth's real audience probably remained circumscribed. Rawnsley quotes the comments of an old Westmoreland cottager: "He wozn't a man as said a deal to common folk. But he talked a great deal to hissen." 27

The point is not that Wordsworth would have been a better poet if he had written in the idiom of the common people. Nor would he have been more honest if he had recognized with Coleridge the impossibility of speaking the language of real people. The point is rather that Wordsworth was involved in an ambitious semiopolitical project that is better understood as emergently self-critical than as an instance of either middle-class hybris or naïveté. It is noteworthy that he does not assume the mantle of original genius in describing his poems and instead calls them an "experiment" ( $L B$, pp. 8, 241) ${ }^{28}$ Lyrical Ballads is an experimental performance of its own project. The split nature of Wordsworth's desired extramural audience registers both hope and anxiety as to how universal his new discourse can indeed be. At the same time in intramural terms this ambivalence is intensified by the ballad's composite social origins and thematized in scenes of textuality and communication within the poems. For the collection already anticipates the gap between its desired and 'real' audience as a discrepancy within its characterized audience. These discrepancies, we shall go on to suggest, are related to discrepancies in Wordsworth's voice. For 'voice' is not some essence that we abstract by bracketing the external world, as classical and preexistential phenomenology would have it. At its origin it is intentional, related to some aspect of the external world, addressed to someone, and reactively shaped by what is outside it.

${ }^{26}$ Jordan, Why the Lyrical Ballads? p. 113; Robert Mayo, "The Contemporaneity of the Lyrical Ballads," PMLA 69 (1954): 518-20.

27 "Reminiscences of Wordsworth among the Peasantry of Westmoreland," quoted in D.

D. Devlin, Wordsworth and the Poetry of Epitaphs (London: Macmillan, 1980), p. 3 .

${ }^{28}$ On this point see also Averill, Wordsworth and the Poetry of Human Suffering, pp. 149-50. 
We can therefore expect the very figures that promote a traditional hermeneutic to be the site of its questioning. A case in point is the thematization of tradition in "Hart-Leap Well." The poem falls into two parts: the first is a straightforward telling of a story about a valiant animal who eludes his aristocratic hunter in death, and the second is a dialogue about the story in the present. But the poem is not just about the survival of a story from chivalric to modern times. It is about the changing frame of values in which that story has survived and thus the historicity of discourses. The bold device of separating the story from the response makes it clear that the poem is about interpretation. Told to Wordsworth by a shepherd whose identity is revealed only in the second part, the story at first comes to us decontextualized, without a characterized narrator or audience. From the perspective of Wordsworth's own time, it seems to reveal the callousness of an aristocratic culture of the hunt. That judgment is implicit in the surrounding context of stories about ordinary people into which this museum-piece is inserted. For though the knight is affected by the animal's death, he is moved not by the wantonness of that death but by its heroism, which allows him to compensate for the fact that the hart has finally eluded his hermeneutic grasp in death by repossessing it as the egotistical selfprojection of his own values. He remembers the animal by building a pleasure-dome which is more for his own use than for purposes of commemoration, and he continues to visit the site with his paramour. But because the story initially lacks a rhetoric of fiction, we are uncertain how to read it. We wonder whether we should trust our own judgments or reconstruct the responses of the original audience, and we are increasingly aware of differences in the possible discourses of reception. We can imagine at least three such discourses: a morally critical response; a response from the knight's peers that praises him for his chivalrous recognition that a mere animal has proved his match in gallantry; and an 'aesthetic' response, a simple absorption in the telling of a tale of suspense and adventure. The vacuum in which the story is relayed forces us to reflect on how we draw the boundaries between story and discourse, and on how much of what we take to be "in" the elementary language of the story is actually figurative. In other words, the fact that this tale is relayed rather than authored by someone who takes responsibility for it makes us reflect on the status of ballads themselves as empty schemas into which different people project their own values.

When the narrator is identified in the second part as a shepherd rather than a minstrel, we discover 'how' to read the story, which now assumes its place among Wordsworth's credal poems, confirming the belief that we should love all things both great and small. We realize that the pleasure-dome was the sign of a culture autocratically imposed on 
nature. By allowing it to decay, nature 'incorporates' a sadness that the point of the hart's story has been missed. Finally, the poet Wordsworth explicitly proclaims this point and brings the poem to a conclusion.

But because of its complicated temporal and hermeneutic framework, the poem asks that we do more than simply extract a message from it. Functioning within the distinction that Godwin was later to articulate between the 'moral' or original intention of a text and its 'tendency' or historically developing meaning, Wordsworth asks us to realize that it is the progress of time that allows for the emergence of his more enlightened reading of the story as didactic pastoral rather than adventure story, as lyric rather than narrative. But to recognize that historical shifts (such as the decline of the feudal aristocracy) produce new modes of understanding is also to situate the understanding that 'Wordsworth' himself achieves. For the scene of the romantic poet reading the chivalric tale internalizes in the poem the situation of a future reader reading Wordsworth's poem. Moreover, Wordsworth is not the teller of the tale, and despite pronouncements to the contrary (l. 162, $L B)$, there is just enough difference between his responses and those of the shepherd to unsettle our assent to his didacticism. The shepherd very simply describes the blight that has descended on the place where the hart died. He reacts to the story by sympathizing with the animal but does not extract general principles from it. For Wordsworth, embarrassed that the shepherd's 'simplicity' and lack of social power make him accept suffering, there is the assurance that things will return to normal through some process for which the responsibility is mystically deferred to 'nature.' Elements of both responses can be located socially. Wordsworth's meliorism and didacticism are functions of his social superiority. At the same time his insistence on a nature that is more than just helplessly sympathetic masks his own fear that he, too, may be able to do nothing but listen. On the other hand, the responses of the shepherd, much more tentatively phrased, bear out (though one might do without the condescension) Coleridge's contention that the rustic conveys "insulated facts, either those of his scanty experience or his traditional belief; while the educated man chiefly seeks to discover and express those connections of things, ... from which some more or less general law is deducible" $(B L, I I, 39)$. Dialogue and narrative retelling make the poem a site for the intersection of cultural discourses and compel us to ask what tradition is. Tradition itself emerges as self-revising rather than confirmative: an agreement to tell the same stories but not a consensus about what those stories mean.

The trope of circulation proves similarly complex as poems cross the fine line between dramatizing figures so as to confirm them and thematizing them so as to question them. A case in point is a poem with the 
cumbersome title: "Lines written at a small distance from my House, and sent by my little Boy to the Person to whom they are addressed." The carpe diem stand taken in the poem is a familiar one. Wordsworth addresses Dorothy and asks her to "Put on with speed your woodland dress, / And bring no book, for this one day / We'll give to idleness" (ll. $14-16, L B)$. The communicative framework of the poem recalls that of the conversation mode: a letter from Wordsworth is sent to his sister by way of the child, urging her to apply what she reads in the letter to her own life, and allowing the poem's 'message' to circulate among a small, intimate community. Yet the elaborate title conspicuously intersects the enthusiasm of the poem itself. At the risk of seeming literal-minded, we may ask why Wordsworth, who is only a short distance from his house, sends Dorothy a letter, the writing of which will surely rupture his bookless communion with nature. And what, we might ask, will be the reaction of Dorothy on reading a letter that exhorts her to stop reading? Such questions make us aware of the artifice involved in the simple life and of the social artifice involved in limiting a plea for rustic indolence to those who are leisured enough to read about not reading. The voice of the poem is a didactic one, though in a light-hearted way. It is obvious enough that writing this voice places its credo in a hypothetical space, especially given that there is no answer from Dorothy. In a larger sense, the replacement of direct speech by letter writing thematizes the position of Wordsworth's lyrics and ballads as a whole: those "songs, poems, and little histories" that he wrote to supplant the "straggling papers" on broadsheets, and that are addressed from a distance to people whose response he does not know. From the inscription of an implied reader in the person of Dorothy arises the troubling question of actual readers, raised by the collection itself as it attempts uncertainly to carry out Wordsworth's dictum that a poet must create his own audience. Who are the audience(s) of nugatory effusions like this one, consisting of lines tossed off hastily and delivered by a child rather than of verses deliberately thought through and distributed by a publisher? Because of the context of this collection, Wordsworth's restriction of his audience to an intimate circle is troubling, at once protective and honest. Perhaps it is no accident that in 1798 this poem comes immediately after "Goody Blake and Harry Gill," a poem about a woman who is too poor to afford firewood, and that in 1800 it is immediately followed by "The Female Vagrant." Stylistically seamless if taken by itself, the poem's framing representation of its textuality becomes the site of its reluctant insertion into the interdiscursive network of the collection, which combines middle and low styles so as to map not simply a prospect in the mind, but a social text. Audiences, as Jon Klancher suggests, "are not simply distinct sectors of the cultural sphere. They are mutually produced as an other- 
ness within one's own discourse."29 To read Wordsworth's lines by themselves would be to let them exist in a distinct cultural sector. Though such a reading is not precluded, we also cannot stop at it. For the issuing of the poems in a collection is a socially symbolic act: a material and visual sign that perceptual spaces are both separate and part of a collectivity, both privileged and relative.

\section{Center and Periphery: Modes of the Personal Voice}

The sense we have that Wordsworth situates his own discourse, rather than claiming for it the bardic authority uneasily appropriated in The Prelude, comes partly from the way he sketches in his function in speaking and listening situations. As we move between the poems, Wordsworth himself moves between center and periphery, between authority and its displacement. Personal lyrics such as "Tintern Abbey" are spoken in a humble version of the egotistical sublime. But Wordsworth the author is often a character in the poems and thus a figure in his own text. As character, moreover, he is of ten a questioner, a visitor, a returning traveler who must elicit information from some local shepherd or sea captain. His intermittent presentation of himself as an outsider marks with a certain tangentiality those poems like the "Lines Left Upon a Seat," where he addresses other travelers such as ourselves from the position of someone who knows the legends and people of the place. If he is not literally an outsider, he is an observer, as in "Old Man Travelling," where the entry of the old man's voice into the monologue suddenly puts Wordsworth outside what he has been observing. For the literal positioning of himself as an outsider in some poems raises the figurative problem of his being outside what he seeks to colonize through his discourse. Again, Wordsworth will of ten present himself as naive: as an adult who knows less than a child in "We are Seven" or "Anecdote for Fathers," and conversely as a child who may know less than an adult in "The Fountain." Not only does he constantly take away the authority he confers on himself, he also plays different roles (adult and youth, insider and outsider) so as to suggest that 'Wordsworth' himself may be a shifting position, a self existing only in relation to other selves and changing as those other selves and future readers change.

But we should not conclude that the interweaving of irony and authority makes understanding illusory. In "The Pet-Lamb" the ballad that Wordsworth sings about the child and her pet lamb is only half hers "and one half of it was mine" (1. 64, $L B)$; and this ballad in turn is about 
the girl's attempt to imagine what the lamb might be feeling, across the recognition that the feelings of animals, even pets, are somehow closed to us. The sense that the languages of adult, child, and lamb can never quite connect is balanced, however, by the sense that the hermeneutic stories we construct to bridge such distances do sometimes produce insights:

"Nay" said I, more than half to the Damsel must belong,

For she look'd with such a look, and she spake with such a tone,

That I almost receiv'd her heart into my own.

(ll. $66-68, L B)$

Crucial to the survival of the hermeneutic project are the various dialogue poems: "Anecdote for Fathers," "We are Seven," and the four Matthew poems. "We are Seven" is a conversation between a cottage girl and an adult male. The child organizes her world imaginatively so as to elide the difference between death and sleep. Convinced that her dead siblings are simply sleeping in the earth instead of in their beds, she is innocent in Blake's double sense: unrealistically lacking in adult sophistication, but also able to see something that is missed by the literalminded 'Wordsworth,' who uncharacteristically invokes a male logic in addressing the poem not to Dorothy but to "dear brother Jim" (l. 1, $L B)$. Constructed around impasses of various kinds, Wordsworth's dialogue poems differ from Marvell's in making us aware of the cultural origins of perception and thus rendering differences relative rather than paralyzingly absolute. They do not simply enunciate positions as economically as possible, but focus on the process by which these positions are conveyed: the characteristic turns and displacements of a person's language. They also differ from Marvell's Manichaean confrontations in their hermeneutic form. They are conversations between people rather than between positions or abstractions. And they are texts that point beyond their own impasses by gesturing toward a reader (dear brother Jim), or placing themselves, as in "The Two April Mornings," in a temporal continuum in which the past is seen from the present and thus the present from the future. Although these poems dramatize the misunderstandings that occur because we speak different languages, they are a powerful enactment of the fact that we do talk in spite of, and perhaps because of, our differences.

We have spoken so far of how Wordsworth relativizes the personal voice by replaying it in ways that raise questions about its authority and reception. But its situatedness is also apparent as a difference within the voice itself and in the forms it assumes. The Wordsworthian discourse is of ten seen as lyrically withdrawn from social commitments. This lyri- 
cism, however, must be understood as intentionality rather than achieved form. The first question to ask is how the personal voice is "composed": both in the sense of being made out of composite elements, and in the sense of claiming a composure that elides its interdiscursive composition. For there are at least two modalities of this deceptively unified voice: the voice of personal feeling and the didactic voice. In a poem like "She Dwelt Among the Untrodden Ways," no attempt is made to go beyond the overwhelming feeling of loss caused by Lucy's death. In a poem like "Lines written at a small distance," surrender to the joys of the moment is assertively generalized into a creed. Of ten the two modes are intertwined, as in "The Old Cumberland Beggar," where absorption in the movements of the beggar abruptly gives way to an assertion of his social utility. In the context of this intertwining, both sentimental absorption and didacticism cease to be positive terms and disclose themselves through the differences between and within them. Credalism emerges as an anxious response to the helplessness of simply contemplating suffering or the hedonism of a "wise passiveness." Pragmatic and ethical, the didactic voice sometimes guiltily takes the place of a social activism that would ameliorate rather than simply watch suffering, but then defers amelioration from man to nature. Sometimes this voice responds to an implied criticism of romantic sensibility, the almost aestheticist absorption in feelings or landscapes for their own sake, as being without larger social utility. Inevitably, the didactic voice is complicated by the undercurrents of what it does not say. But the sentimental voice does not achieve ideological autonomy either, since its very passivity marks it as a voice of retreat that concedes the impossibility of changing conditions that the contemplation of suffering makes us want to change.

Divided at its origin into active and passive modes, the personal voice also takes up residence in forms that are curiously mixed and that keep rereading themselves. Of ten the Lyrical Ballads are seen as subordinating a situation to the feelings it arouses so as to convert narrative, with its implication in the world of events and social change, into a spot of time sealed in lyrical stasis. Wordsworth himself speaks of how the feeling developed in these poems "gives importance to the action and situation and not the action and situation to the feeling" ( $L B$, p. 248). But the antinarrative elements in poems that are also part of a developing tradition of regional realism give the ballads as much affinity with the short story as the lyric. The short story can be seen as a frustrated lyric. It shares with the lyric an abridgment of time and a transcendental impulse evident, for example, in Joyce's epiphanies, which suddenly switch the reader from a despairingly realistic frame of values to one that is symbolist or anagogic. But because empirical details are more insistently present in the short story than in the lyric, the voiding of the realistic dimen- 
sion seems more evasive. The truncation of plot registers as paralysis, suspending the form between the inability to place an episode in a connective framework that will explain its ugliness and the desire for a visionary transcendence that will abrogate the need for such explanation. An example of the poem as short story is "The Thorn," which focuses obsessively on the spot where an unwed mother is said to have disposed of her child. Taking form as a series of anxious rhetorical questions, the old captain's monologue pivots on a single traumatic scene, a scrap from a sensational tabloid. In his attempt to place this fragment, he desperately lyricizes it. He reduces Martha Ray's story to the feelings it arouses, and he makes the scene with which he associates her into a symbolic landscape in which the thorn weighed down by lichens embodies the harshness of life. Visionary dreariness, however, is constantly interrupted by the obsessive factual details about the dimensions of the thorn that so annoyed Coleridge, and that make lyricism seem like a symptom of the narrator's dislocation rather than a successful transmutation of trauma. The flood of questions and the framework of the poem, in which a story is being told rather than a mood created, militate against any reduction of Martha's life to a spot of time and leave us wanting to know more about what happened and the community where it happened.

Though they displace lyrical intention, Wordsworth's "short essays," as he described them ( $L B$, p. 247), do not always deconstruct lyric as avoidance. In "The Idiot Boy" the effect is more that of a palimpsest. The idiot boy never does come back with the doctor, but he eventually returns with the statement "The cocks did crow to-whoo, to-whoo, / And the sun did shine so cold" (ll. $460-61, L B$ ). On a realistic level the poem troubles us with what might have happened to Johnny and Susan, and with the isolation of these two old women who have no one to depend on but a retarded boy. Superimposed on the realistic details of the story, which are all too familiar from ballads about the poor, is the narrator's emphasis on the feelings of anxiety and pride aroused in Betty Foy and the epiphany experienced by Johnny, both perhaps unfamiliar to a middle-class audience who can only look at the poor 'realistically.' Yet we are not entirely convinced that the almost tragic story can be comfortably reread on the plane of feeling as in pure lyric. For one thing, Johnny's ephiphany, expressed in two lines that may be proto-imagist or merely prosaic, is oddly flat. We are thus unsure whether the epiphany is his or ours, the product of a guilty humanism that makes us want to attribute value even to idiots. The poem hovers uneasily between lyric and realism, suggesting that each is a compensatory response to the other, and each is a mode of reading that is partially true.

Because the heterogeneity of Lyrical Ballads foregrounds the issue of discourse, the poems must be read not just for what they say but also as 
exhibiting self-critically their own forms of awareness. A brief example is "Old Man Travelling." Obviously a dress rehearsal for "Resolution and Independence," the poem moves closer to making the old man a mere occasion for poetic insight in the 1815 revision, in which the last six lines are eliminated. Many critics have been embarrassed by the 1798 version's rude interruption of its visionary mood, as the old man tells 'Wordsworth' that he is not tranquilly living in the eye of nature but is journeying to see his dying son in a hospital. But it is clear that the original poem is deconstructed around the discrepancy between lyrical and narrative frames of value, so as to play the one critically against the other in a way that makes it a paradigm for other discursively complex poems in the collection. Wordsworth's description of the poem as a 'sketch' already makes us aware that its sentimental characterization of the old man is hesitantly brief. A sketch is not a realistic portrait: it provides outlines rather than interiors and reflects the casual perceptions of the artist rather than objective truth. Sketching is, moreover, a leisure-class activity. From the assumption that the situation of the old man is less important than the feelings it arouses in the spectator, 'Wordsworth' moves quickly to humanize the possible absurdity of the man's life through an existential romanticism that makes the aimlessness of life's journey less significant than the responses that occur in our mental travel and that are their own reward. The shift from 'Wordsworth's' lyrical meditation to the old man's short, bare account of where he is going makes us abruptly aware of the gulf that separates their two discourses: the one privileged in being able to attribute value to life by displacing detail from the literal to the symbolic level, and the other not necessarily more 'true' but excluded from metaphysical consolation. In the old man's statement there are only facts, no feelings:

-I asked him whither he was bound, and what

The object of his journey; he replied

"Sir! I am going many miles to take

"A last leave of my son, a mariner,

"Who from a sea-fight has been brought to Falmouth,

And there is dying in an hospital."

(ll. $15^{-20, L B)}$

These lines are indeed "uninteresting," in Robert Langbaum's phrase, ${ }^{30}$ in the sense that they provide no personal insight into the old man. But they convey a troubling social insight, namely, that feelings may not be shareable. Perhaps in the old man's sociolect, feelings are not important: perhaps one has them but does not express them, because what one shares is information. Or perhaps the old man feels that information is

30"Wordsworth's Lyrical Characterisations," p. 330. 
all that can be shared across the boundary dividing him from 'Wordsworth.' That the poem ends with this uncertainty is significant for the hermeneutics of feeling so crucial to this collection. 'Wordsworth' could have responded to the old man and generated a conversation in which the man would have expressed his grief over his son or his indignation over the war. Such a continuation would have punctured 'Wordsworth's' view of the old man as content, but only to replace one feeling with another, since the two men would still have been bound together in the shared feeling of an inconsolable loss. But instead 'Wordsworth' awkwardly drops the conversation. That the author in the original version puts the old man's speech in quotation marks is also significant, for the old man thus remains unappropriated into 'Wordsworth's' discourse. But already in 1800 the effacement of difference begins. The old man's account is now conveyed as reported speech, located in the past as a spot of time and thus placed, psychologically as well as orthographically, within 'Wordsworth's' own language.

\section{"The Old Cumberland Beggar" and "The Brothers"}

Poems like "Old Man Traveling" which deliberately plays one language against another, sensitize us to the duplicities in texts whose rhetoric is more seamless, and encourage us to read symptomatically the hermeneutics of sentimentalism that frames so many of these poems. We conclude by looking at two poems that seem to support the ideology of the personal voice but that also reproduce (not always deliberately) some of its tensions. The more obviously political of these poems is "The Old Cumberland Beggar." According to the Fenwick note, it was written to defend the individual rights of beggars against the political economists who threatened to sweep them away into state-run poorhouses. In place of such collective solutions the poem describes a conservative, community-based welfare in which the beggar makes his rounds from house to house, and the process of alms-giving remains personal rather than commodified. So old that Wordsworth remembers him seeming just as old when the poet was a child (ll. 22-23, $L B$ ), the beggar is a local tradition and circulates among the local people, becoming the occasion for a social hermeneutic:

While thus he creeps

From door to door, the Villagers in him

Behold a record which together binds

Past deeds and offices of charity

Else unremember'd.

(ll. $79-83, L B$ ) 
The poem at many points echoes the conversation poems, in its evocation of "A life and soul to every mode of being / Inseparably link'd" (ll. $78-79, L B$ ), and most of all in its benedictory conclusion (ll. 155-189, $L B)$. As a poem about a beggar, it is thus crucial to Wordsworth's project of moving beyond coterie poetry and claiming universality for the conversational vision. Were the text to consist only of the poem, we might well see it as affirming this social hermeneutic, though unconvincingly. But "The Old Cumberland Beggar," as it now comes to us, breaks up into three repetitive intertexts. The text itself consists of a headnote that defends individual rather than institutional solutions to poverty, and a monologue oddly divided between meditative and propagandistic voices, between aesthetic and political defenses of this solution. To this amalgam of discourses we must add the frustrated Fenwick note of 1843 whose attack on political economists has no clear referent, since it seems to expose the commodified structure of the philanthropy advocated in the poem, in the very process of criticizing the system of socialized charity that is about to displace such philanthropy. The redundancy of the poem's structure, combined with the need years later to supplement the headnote with an explanatory footnote, gives the impression of someone who does not quite know what he is saying, in the midst of the various discourses that speak through him. Composed as it is of texts that displace rather than satisfactorily comment on each other, "The Old Cumberland Beggar" enacts Wordsworth's attempt to place the old beggar within various discourses, each anxiously positive, and yet each produced partly as an otherness within the discourse it rejects.

The simplest of the intertexts is the headnote, which laments the passing of a system in which local communities look af ter their own, and in which the philanthropy attacked by Blake in "The Human Abstract" really does seem consistent with a respect for the beggar's autonomy. Yet in the poem itself, which breaks up into two divergent sections, respect for the beggar's individuality and the attempt to integrate him into an economy of sentimental values seem curiously at odds, in ways that make us uneasy with both rhetorics. The poem begins with a detailed description of the beggar already divided in the effect it produces. The description is not so much sentimental as aesthetic: every detail of the old man's activity is observed with a negative capability that makes no attempt to fit him into any moral scheme. Like some character in a Beckett novel, he arranges his "scraps and fragments" and scans them "with a fix'd and serious look / Of idle computation" (ll. 11-12, $L B$ ). In the context of the headnote we see this non-judgmental recording of his most trivial motions as respectful of his right to exist as he is. At the same time, the meticulous painting of the beggar turns up a plethora of troubling details that make us suspect a certain callousness in this respect for the 
beggar's individuality. His hand is so palsied that he drops the crumbs of his meal and inadvertently shares them with the little birds (ll. 16-21, $L B)$. He is so bent that he sees only what is on the ground and scarcely knows what he sees (ll. 45-51, $L B$ ). As the careful observation of the beggar proceeds, it generates two overlapping perceptual frames: a romantic perception of everything that lives as holy, and a materialist awareness that these are after all the signs of poverty and that "Beauty is truth, truth beauty" may not be all we need to know. The long section beginning "But deem not this man useless" $(\mathrm{l} .67, L B)$ arises as a way of eliding the uneasiness that Wordsworth feels, by assuring us that something is being done to help the old man and that he can be helped without removing him from "that vast solitude" where he is able to roam freely in all seasons (1. 156, $L B)$, an aged version of the child in "Frost at Midnight" and a token that the romantic vision of the one life survives even in poverty.

The nervous verbosity of this section reminds us of the insincerity in this typically sentimental form of charity, in which people give alms to the poor in order to watch themselves being compassionate. But what is equally interesting is that Wordsworth in the Fenwick note unwittingly converts an attack on the other into an attack on himself. He begins by criticizing the reification of charity: "The political economists were about that time beginning their war upon mendicity in all its forms, and by implication, if not directly, on Almsgiving also." But he continues by attacking a system of voluntary charity which could well refer to the philanthropic chain praised in the poem:

This heartless process has been carried as far as it can go by the AMENDED poor-law bill, though the inhumanity that prevails in this measure is somewhat disguised by the profession that one of its objects is to throw the poor upon the voluntary donations of their neighbours; that is, if rightly interpreted, to force them into a condition between relief in the Union poorhouse, and Alms robbed of their Christian grace and spirit, as being forced rather from the benevolent than given by them; while the avaricious and selfish, and all in fact but the humane and charitable, are at liberty to keep all they possess from their distressed brethren. ( $L B$, p. 306$)$

What is puzzling here is that Wordsworth attacks the state for throwing the poor "upon the voluntary donations of their neighbours": in other words for reinstating precisely the system it is accused of eliminating. Brought back as a response to the poor laws, voluntary charity no longer seems attractive or even voluntary. But the reinscription in bad faith of what Wordsworth himself advocates discloses an uncomfortable sense that voluntary charity may always have contained traces of commodification. Granted that the poem describes charity given "with Christian 
grace." Nevertheless this charity is a matter of "habit," of "The mild necessity of use" (ll. 91-92, $L B$; italics mine). Moreover, it is difficult to deal with Wordsworth's second objection without running afoul of his first one. One cannot invent a form of charity that includes "the avaricious and the selfish" in that participatory bonding necessary to a sense of community without some system of taxation that would impose a collective will on the individual. Where the headnote simply contrasts two ways of dealing with beggars, one humane and the other callous, the Fenwick note confuses our sense of a right way to deal with social problems by suggesting that all economic solutions to poverty are divisive and devalue the individuals they are meant to serve.

The intertextual effect of the Fenwick note is a curious one. The poem by itself might simply have provoked us to continue the progress from aesthetic to social consciousness by imagining a way of reintegrating the beggar into the community less condescendingly than the one 'Wordsworth' so blusteringly affirms. Blocking a hermeneutics of enlightenment that tries to 'improve' the poem, by inscribing such a reading in the very meliorisms it corrects, the Fenwick note makes us reevaluate the 'aesthetic' consideration of the beggar at the beginning. But this discourse reenters the interpretive field by default and can have no more than a supplementary status. The various 'economic' discourses (including our own) treat the old man as a sign, as part of a system of exchange in which he represents something to someone else. The aesthetic discourse of the beginning treats him as a symbol, as someone whose meaning is in what he is, and therefore as an end in himself. Even granting its privatism, the bracketing of all concerns about what the beggar represents to society affords us an insight into his uniqueness that is possible only within a 'romantic' discourse we too easily dismiss as dated. And yet this very insight is blind to the old man's material needs, as is apparent from Wordsworth's need to supplement it with the account of how the beggar is looked after. As the poem compels us to think about both aesthetic and economic discourses, so also it allows us to question the paternalist moral economy that 'Wordsworth' defends, but not to dismiss it. However the twentieth-century left may resolve the problems of another age, it is worth remembering E. P. Thompson's comment that "the Plebeian culture" of Wordsworth's time "is rebellious, but rebellious in defence of custom." ${ }^{11}$ Blusteringly affirmative on the surface, the effect of the poem is actually to play one discourse against another so as to bring out how they exclude each other and yet must uneasily cohabit in a social consensus that is dialogic rather than traditionally hermeneutic.

31 “Eighteenth-Century English Society: Class Struggle without Class?” Journal of Social History, 12 (1978): 154. 
Our final example uses many of the figures of understanding familiar from the other lyrical ballads. "The Brothers" is the story of two orphans: the older brother, Leonard, who goes to sea at the age of thirteen to earn a living, and the younger brother, James, who is then adopted by the community but mysteriously dies. The poem consists of a dialogue between the priest and Leonard, who has returned in search of James, only to find a new grave in the cemetery and to hear that one of the 'brother fountains' with which he associates himself has disappeared. Reading the poem uncritically, we might say that it incorporates the story of the brothers' love into the natural scene and then preserves this story through tradition and conversation. Significantly, the graves are all unmarked. To Leonard's comment that such unnamed graves in no way mark the fact of death, the priest replies that the stories of the dead are kept alive orally:

We have no need of names and epitaphs,

We talk about the dead by our fire-sides.

(ll. $179-80, L B)$

Even more intriguing is his comment that for death "we want / No symbols, Sir, to tell us that plain tale" (ll. $181-82, L B$ ). A language of facts that are unre(mark)able, the plain tales of people's lives and deaths need neither symbols nor writing, because there is no disagreement about what they mean. They simply are, and their elemental truth is reaffirmed in conversations with those who share the bond of humanity. Crucial to our own inscription in the poem's hermeneutic is the inclusion of Leonard as both participant in the tragedy and implied reader. Through Leonard, who at first seems like us a mere visitor in the poem, we, too, become spectators ab intra, participants in an economy that circulates and reconfirms the values of sentimentalism.

The reading described here depends, however, on our investing the "homely Priest of Ennerdale" with the same authority ascribed to the pastor in The Excursion. Yet the poem opens with a lighthearted interlude between the priest and his wife Jane, in which he mistakes Leonard for a tourist. He never does recognize Leonard as one of the brothers whose story he tells, and we are left wondering why Wordsworth presents him as mildly obtuse if we are supposed to accept his responses. The question is best approached by asking what exactly the discourse is that the priest creates out of the brothers' story and how he is characterized as reader. Being hermeneutically naive, he is not conscious that he is doing any more than tell a story or that its 'lesson' is not similarly part of the order of mimesis. The world is "a great book" (l. 270, $L B)$ made by God, and in it he reads the message of this story, which is that the 
brothers' mutual devotion shows a touching 'piety' (1. 271, $L B)$. The priest's account of the parents' death and of why Leonard went to sea is relegated to prefatory segments of the narrative, and his emphasis is on the virtues that were thereby brought out in the boys: the fraternal love that made Leonard leave to earn money for his brother, and the loyalty that made James pine for his brother to the point of sleepwalking and 'accidentally' falling to his death. The possibility of suicide is elided, because such an un-Christian death might raise the question of whether a pietistic discourse is the right framework in which to read this story. The priest, in other words, uses the story to create a discourse built around virtue. Because of the lyricizing emphasis on feeling, and because the story unfolds entirely in the past, being told rather than dramatized, we have a distancing sense of fatalism, a sense that things could not have happened differently.

One does not question the deep feelings that underlie the brothers' relationship. Yet there is something incomplete about an interpretation that turns the story into a spot of time associated with the place where the brother fountains once were and then treats it as a memorial relic that is circulated but never questioned. The fiction of a community that shares experiences like death and loss is troubled narratively by the fact that the younger brother, James, though he was "the child of all the dale" and "liv'd / Three months with one, and six months with another" (ll. $353-54, L B$ ), never really feels at home in the happy valley after Leonard's departure. It is troubled hermeneutically by the fact that there never really is any communication between the priest and Leonard, who reveals his identity only after leaving, and then, too, his identity but not his thoughts. As unsettling is the reversal of Wordsworth's usual convention of making the hearer of the tale a spectator $a b$ extra who is initiated into communal lore by a native of the place. Because Leonard, the apparent outsider, turns out to be more within the story than the priest, and yet because he asks questions but never tells his story, we are left wondering whether we have indeed got inside the story. As in so many of these poems, the socioeconomic context has been curiously muted though not entirely omitted. We wonder why the boys' parents both died, and what led to the failure of a farm that had been in the family for five generations. The latter is presented as an isolated occurrence in a valley that has otherwise remained the same. But given that Walter Ewbank worked hard, is it credible that his failure is not part of some larger economic crisis elided from what the priest says? Leonard's reticence in front of the priest clears a space in which the reader can begin to tell the story differently. For the point about the genre of social history as opposed to sentimental narrative is that although the story itself does not change, the responses do. The lyricizing 
discourse of the feelings naturalizes tragedy: "For accidents and changes such as these, / Why we have a store of them!" (ll. 147-48, LB). Memory, its principal agent, can be a profoundly conservatizing force, because it composes the details of an experience in one particular way and then seals it in the past. The more materialist and historicist idiom that culminated in the Marxist rearticulation of temporality as history finds causes for social calamity and looks for solutions. We never really know whether Leonard's concluding silence marks his consent to the poetry of human suffering or his failure to find different words: his restless and still unformed sense that his family's tragedy did not have to happen after all.

At the heart of the poem's ambiguity is its invisibly symbolic mode, which is curiously at odds with the priest's claim, "We have no need of . . . symbols." For the interpretation of the poem as a spot of time that incorporates the virtues of loyalty and brotherhood among the forms of nature is dependent on a symbolic connection between the brothers and the 'brother fountains.' Yet the meaning of the fountains is far from clear. We can read the disappearance of one of the fountains two years after the death of one of the brothers as nature's sanctification of their relationship and her admission that the death of such a special person does make a difference. But the event that causes the fountain to disappear (the rending of a huge crag by lightning) is cataclysmic, hardly of the same order as the plowing and spinning with which the priest compares it. Perhaps the event means that the suicide of one so young is a breach in nature, something the community could have tried to prevent. The epitaphs and tombstones absent from Ennerdale serve the pragmatic function of identifying the dead that Leonard attributes to them. In a more profound sense, however, they encrypt the dead: they make the lives of the dead cryptic rather than transparent. A tombstone marks the fact of representation by creating a boundary between the presence and now the impenetrable absence of the dead, and our attempts to represent them. On the other hand, the unnamed graves are like the effaced coin in Nietzsche's famous discussion of truth and lie. Claiming as they do to tell a plain tale, these graves express the will of a community that has effaced not only the faces of the dead but also the metaphors that inhabit its own consolatory truths. For the unnamed graves, by making death commonplace, elide the scandal of the individual death. They permit the unquestioned circulation of stories that place particular deaths and that thereby keep in being the values that sustain a conservative psychic economy.

As an act of circulation itself, the poem is powerfully committed to uniting text and reader in a pathos that overwhelms any desire to ask questions. But on another level it also divides that pathos, causing it to 
speak its own silences. For one thing, the constant references to emblems, symbols, and tales encourage us to read the poem on the level of the signifier. As already suggested, the discrepancy between the priest's claim to be telling a plain tale and the poem's symbolic mode intimates a larger uneasiness with plainness: with the collection's project of an elementary language that is beyond representation because it achieves an exact equivalence between what is said or felt and what really is. This uneasiness emerges as an awareness of the customary origins of the languages we speak, of the language that the priest speaks, perhaps on behalf of Wordsworth himself. For where pure lyric is unsituated and thus universalizes its language, the opening domestic sketch of the priest marks his language as socially generated, and the dialogue format gives the reader a vantage point outside this language. One final factor is even more significant in making the text the site of the reader's dialogue between the poetry of human suffering and the prose of the world, and that is Wordsworth's realism: that attention to detail which Coleridge criticized as matter-of-factness, and which tells us how long the family had owned the farm and how great the age difference between the brothers was. The combination of precise factual detail with a certain vagueness about facts acts as a heuristic stimulus that provokes us to ask practical questions that we would not ask of a poem like Adonais, while making us wonder whether such an irritable reaching after fact does not miss the point. This intertwining of lyric and realism, in other words, dislodges us from comfortable tenancy in the discourse of the affections, a discourse whose power to move us must be balanced against its tendency to make feeling an end in itself. ${ }^{32}$

This discussion of a lyricizing romantic discourse that deflects social consciousness has obviously benefited from the work of Marxist and new historicist critics on the romantic repression of history. ${ }^{33}$ My emphasis, however, is different. For one thing, the displacement of the reader that makes such a discussion possible does not result in the replacement of Wordsworth's desired reader with a real reader able to dismiss lyric as a form of repression. We cannot determine what Wordsworth's real audience was, and if we could, that would not establish what his real au-

\footnotetext{
$32 \mathrm{On}$ a thematic level, too, Wordsworth seems critical of the affections, and suggests that they contain a destructive element, as Frances Ferguson argues: Wordsworth: Language as Counter-Spirit (New Haven, Conn.: Yale University Press, 1977), pp. 48-49. He is critical, too, of the imagination. "The Brothers" comes immediately after "There Was a Boy," and the description of the "feverish passion" with which Leonard on his travels sees the landscape reflected in the water and projects into it the uncertain heaven of his native valley recalls the final lines of the lyric on the Boy of Winander.

${ }^{33}$ See the work of Klancher and Levinson already cited; James Chandler, Wordsworth's Second Nature (Chicago: University of Chicago Press, 1984); Alan Liu, Wordsworth: The Sense of History (Stanford, Calif.: Stanford University Press, 1989).
} 
dience $i$ s. Such a determination, moreover, would oversimplify the 'real' by assuming that it is a positive essence rather than a differential relation between antonyms such as 'desired,' or 'ideal.' Though reader-response theory is often accused of approaching the reader in an insufficiently materialist way, literalizing the notion of audience by identifying it with a specific historical group is equally essentialist and has value more as a corrective than as truth. There are advantages to defining 'audience' as a blank that can be filled in more than one way, while defining the audience-oriented text as an unstable compound of voices that can never quite be fixed. Where Marxist criticism might fix the text once and for all as a flawed product of its times, the historicizing of hermeneutics that Lyrical Ballads ultimately invites sees the very nonidentity of the text as one of the factors that makes it a productive stimulus as well as 'situating' it.

Second, it is incorrect to speak of repression, given that the 'romantic discourse' is never anything more than a project. Eschewing monumental writing, the Wordsworth of the prelaureate years allows his lyricizing of plot and situation to be caught within a contrary movement toward the novelizing of lyric. Embedded in the broadside ballad are traditions of populism, of political concern and social protest that Wordsworth effaces in the 1815 rearrangement but calls into play in this collection. A lyrical ballad is not a lyric: it is a composite form that is the site of heuristicially productive tensions. These tensions do not emerge through a later and more enlightened reading but are built into the poems themselves. Wordsworth does indeed want a world where different social selves cohabit, rearranged in an order that is horizontal rather than hierarchical, but in a rural rather rather than urban world that is tolerant because it is also spacious. But the collage of discourses collected in the Lyrical Ballads does not finally, as Jon Klancher argues, shade "into the Romantic poet's pluralist blending of differences." 34 As importantly, these differences do not simply undermine the discourse of the private self. Ultimately because of its focus on how we constitute the world through perception and because of the perspectival format of a collection composed of poems spoken in different voices, Lyrical Ballads asks us to accept the romantic discourse as no less legitimate than any other, though incapable of being insulated from what it deflects and always a differential rather than a positive term.

${ }^{34}$ English Reading Audiences, p. 148. 